\title{
RANCANGAN SISTEM OTOMASI PERPUSTAKAAN BERBASIS WEB DENGAN MENGGUNAKAN "SLIMS 9.0" PADA POLITEKNIK PARIWISATA MAKASSAR
}

\author{
Kusmawati', Muhammad Anas ${ }^{2}$ \\ ${ }^{1,2}$ Politeknik Pariwisata Makassar, Jl. Gunung Rinjani, Kota Mandiri Tanjung Bunga, Makassar \\ ${ }^{1}$ kusmawaty@poltekparmakassar.ac.id, ${ }^{2}$ mail.nazta@gmail.com
}

\begin{abstract}
ABSTRAK
Penelitian ini dilakukan di Politeknik Pariwisata Makassar dengan menggunakan studi banding dan studi literatur. Tujuan dari penelitian ini adalah untuk merancang lalu menerapkan salah satu aplikasi open source yaitu SLiMS versi 9.0 (Bulian) yang akan digunakan di Politeknik Pariwisata Makassar untuk mengoptimalkan pemanfaatan teknologi informasi, sehingga memudahkan pengelola perpustakaan untuk meningkatkan pelayanannya serta memudahkan pengadiministrasian koleksi buku yang ada di perpustakaan. Adapun tujuan dari penelitian ini adalah Pemanfaatan teknologi informasi dalam perancangan sistem otomasi perpustakaan di Poltekpar Makassar yang sesuai dengan kebutuhan pengguna, peningkatan kunjungan anggota perpustakaan dengan adanya sistem otomasi perpustakaan di Poltekpar Makassar, peningkatan layanan di Perpustakaan Poltekpar Makassar. Aplikasi SLiMS Versi 9.0 (Bulian) adalah aplikasi yang tepat digunakan karena penggunaannya yang cukup mudah untuk dimengerti, dan aplikasi ini bisa diakses secara online maupun offline.
\end{abstract}

Kata Kunci : Perpustakaan, Free Open Source, SliMS

\section{ABSRACT}

This research was conducted at the Makassar Tourism Polytechnic using comparative studies and literature studies. The purpose of this study was to design and implement an open source application, namely SLiMS version 9.0 (Bulian) which will be used at the Makassar Tourism Polytechnic to optimize the use of information technology, making it easier for library managers to improve their services and facilitate the administration of book collections in the library. The purpose of this research is the use of information technology in designing a library automation system in the Makassar Poltekpar according to user needs, increasing the visits of library members with the library automation system at the Makassar Tourism Polytechnic, improving services at the Makassar Tourism Polytechnic Library The SLiMS Version 9.0 (Bulian) application is the right application to use because its use is quite easy to understand, and this application can be accessed online or offline.

Keywords : Library System, Free Open Source, Slims 


\section{PENDAHULUAN}

Perpustakaan merupakan salah satu unsur penunjang Perguruan Tinggi. Secara khusus sistem pendukung dijabarkan lagi dalam beberapa aspek, yaitu sistem informasi, sumber daya informasi, infrastruktur fisik dan teknologi informasi, keuangan, sumber daya manusia, kerjasama dan layanan. Begitu pula dengan Perupustakaan Politeknik Pariwisata Makassar.

Layanan Perpustakaan di Politeknik Pariwisata Makassar selama ini belum memaksimalkan penggunaan teknologi informasi dalam sirkulasi layanannya. Dalam hal ini, perpustakaan tentunya membutuhkan bantuan teknologi guna mempermudah dan mempercepat kerja para pustakawan dalam berbagai aspek, seperti pengadaan, pengolahan, display, sirkulasi/ pelayanan serta perawatan bahan pustaka. Teknologi sangat berperan penting dalam perkembangan perpustakaan ke arah yang lebih maju [1].

Ketidakoptimalan layanan di Perpustakaan Politeknik Pariwisata Makassar disebabkan oleh beberapa hal, antara lain :

1. Tidak adanya pustakawan di kampus Politeknik Pariwisata Makassar, sehingga sirkulasi pelayanan buku ataupun sistem yang ada tidak jelas.

2. Kurangnya minat baca mahasiswa.

3. Pelayanan yang kurang maksimal.

4. Pengaturan buku di rak kurang menarik perhatian.

5. Kurangnya sarana dan prasarana di perpustakaan untuk membantu mahasiswa mencari referensi, baik itu berupa buku ataupun jurnal-jurnal.

Salah satu bentuk memaksimalkan penggunaan teknologi informasi adalah dengan menerapkan sistem otomasi perpustakaan yang meliputi hardware dan software. Menurut Cohn, otomasi perpustakaan merupakan sistem yang mengkomputerisasikan beberapa kegiatan yang dilakukan pada perpustakaan tradisional seperti, kegiatan pengolahan bahan pustaka, sirkulasi, katalog publik (OPAC), pengadaan (akuisisi), manajemen keanggotaan, pengelolaan terbitan berseri. Semua kegiatan tersebut dilakukan dengan menggunakan pangkalan data (database) perpustakaan sebagai pondasinya [2]. Lebih sempurna lagi, apabila sistem otomasi perpustakaan dilengkapi dengan barcoding, dan mekanisme pengaksesan data berbasis web dan internet [3].

\section{TINJAUN PUSTAKA}

Menurut UU Perpustakaan pada Bab I pasal 1 menyatakan Perpustakaan adalah institusi yang mengumpulkan pengetahuan tercetak dan terekam, mengelolanya dengan cara khusus guna memenuhi kebutuhan intelektualitas para penggunanya melalui beragam cara interaksi pengetahuan. Di dalam buku UU No. 43 Tahun 2007 Pasal 1 ayat 1, Perpustakaan adalah istitusi pengelola koleksi karya tulis, karya cetak, dan/atau karya rekam secara professional dengan sistem yang baku guna memenuhi kebutuhan pendidikan, penelitian, pelestarian, informasi dan rekreasi para pemustaka [3].

Perangkat otomasi yang dimaksud disini adalah perangkat atau alat yang digunakan untuk membantu kelancaran proses automasi. Perangkat ini terdiri dari 2 (dua) bagian yakni Perangkat Keras (Hardware) dan Perangkat Lunak Otomasi (Software) diantaranya sistem SLiMS (Senayan Library Managemen System).

SLiMS dikembangkan menggunakan kolaborasi beberapa perangkat lunak berbasis open source, antara lain Apache sebagai web server; HTML (Hypertext Markup Language) adalah bahasa standar yang digunakan oleh browser untuk menampilkan informasi dalam halamanhalaman web; PHP (Hypertext Preprocessor) adalah bahasa script yang disisipkan dalam HTML yang digunakan sebagai bahasa pemrograman web; dan MYSQL adalah sistem manajemen database yang digunakan untuk menyimpan semua data. Semua perangkat lunak ini dibangun dengan kode sumber (source code) yang bersifat terbuka (open source). Melalui modul yang cukup lengkap, SLiMS dapat membantu pihak manajemen untuk membuat kebijakan pengadaan atau sebagai bahan pertimbangan untuk memutuskan suatu kebijakan bagi pengembangan perpustakaan. semua kegiatan ini mungkin dilakukan dengan modul Bibliografi, Sirkulasi Keanggotaan, OPAC (Online Public Access Catalog), Inventariasi Koleksi, Master File, Sistem Pelaporan dan Kontrol Terbitan Berseri. Berikut ini adalah gambar konsep komponen dari sistem informasi [4].

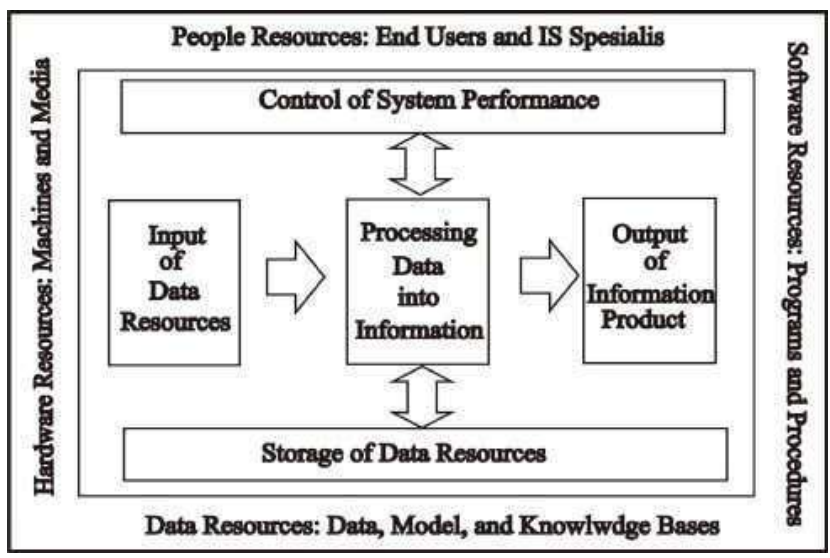

Gambar 1. Konsep Komponen Sistem Informasi

\section{METODE YANG DIUSULKAN}

Jenis penelitian ini adalah penelitian kualitatif dengan menggunakan pendekatan deskriptif naratif dan bentuk penelitian menggunakan studi kasus. Proses penelitian ini mengajukan pertanyaan-pertanyaan, mengumpulkan data yang spesifik dari para partisipan, menganalisis data secara induktif dan bertema khusus ke tema umum [5]. Pendekatan deskriptif dilakukan untuk mengetahui keberadaan variable mandiri, baik itu variable yang berdiri 
sendiri maupun variable bebas tanpa membuat perbandingan itu sendiri dan mencari hubungan dengan variable lain [6]. peristiwa yang dipilih yang selanjutnya disebut kasus adalah hal yang actual (real life events), yang sedang berlangsung, bukan sesuatu yang sudah lewat [7].

Informan dalam penelitian ini ialah pustakawan yang memanfaatkan sistem otomasi di Perpustakaan Universitas Islam Negeri Alauddin Makassar, dan di Universitas Mega Rezky Makassar. Selain itu informan yang tak kalah pentingnya adalah pengelola perpustakaan Politeknik Pariwisata Makassar sebagai pengguna yang akan memanfaatkan sistem otomasi perpustakaan ini yang disesuaikan dengan kebutuhan penggunanya.

Terkait dengan teknik pengumpulan data pada penelitian ini, penulis menggunakan dua cara, yaitu:

1) Penelitian kepustakaan (library research) yaitu pengumpulan data dengan menggunakan buku-buku literatur atau kepustakaan yang ada hubungan dengan masalah yang diteliti, baik dikutip secara langsung maupun tidak langsung yang relevan dengan judul yang diteliti.

2) Studi lapangan (field research) yaitu penelitian langsung yang dilakukan langsung terhadap objek yang diteliti dengan cara observasi dan wawancara. Teknik ini melakukan wawancara langsung terhadap responden agar menjawab pertanyaan-pertanyaan lisan yang berkaitan dengan masalah yang akan diteliti dengan tujuan untuk melengkapi data pokok.

Teknik pengolahan dan analisis data dalam penelitian ini adalah analisis data kualitatif, merupakan teknik yang bersifat non-statistik. Mile dan Hubermen dalam Bancin [8], menyebutkan ada tiga langkah pengolahan data kualitatif, yakni reduksi data, penyajian data, dan menarik kesimpulan/verifikasi. Kesimpulan ini dapat berupa kausal atau interaktif, maupun hipotesis atau teori [8].

\section{HASIL PENELITIAN}

Berdasarkan penelitian yang dilakukan, maka penggunaan aplikasi SLiMS, yang merupakan aplikasi Free Open Source dalam arti aplikasi ini digunakan secara gratis dan dimodifikasi sesuai dengan kebutuhan pengguna. Di Perpustakaan Politeknik Pariwisata Makassar, karena sistem yang digunakan masih manual, maka dari itu, , pengaplikasian sistem otomasi perpustakaan ini dirasa tepat untuk membantu mengoptimalkan pelayanan di perpustakaan.

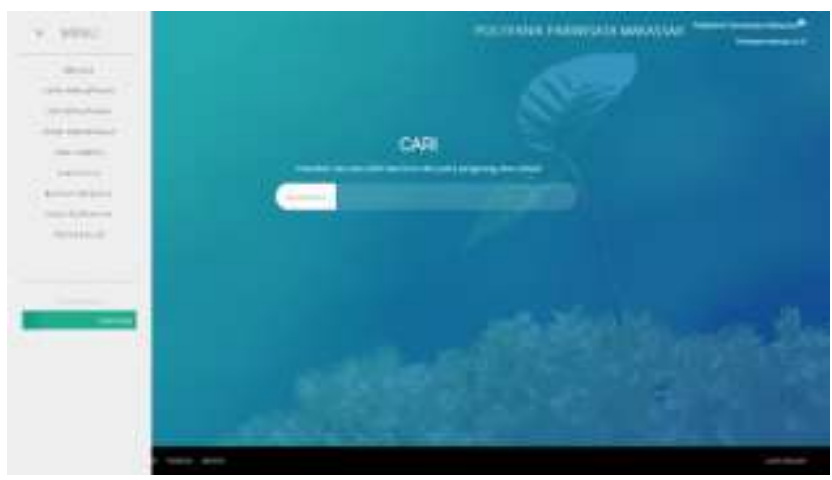

Gambar 2. Tampilan Menu Aplikasi SLiMS pada Admin (OPAC)

Beberapa menu yang bisa dikonfigurasi oleh pustakawan atau pengelola aplikasi ini berdasarkan menu yang terdapat di SLiMS sebagai berikut:

a. Beranda, di menu ini, data yang ditampilkan adalah data jumlah koleksi, data jumlah item, data buku yang dipinjam, dan data buku yang tersedia. Selain itu, di menu ini juga terdapat pilihan menu untuk mengubah profil pengguna (pustakawan / pengelola aplikasi) dan pengaturan pemintas.

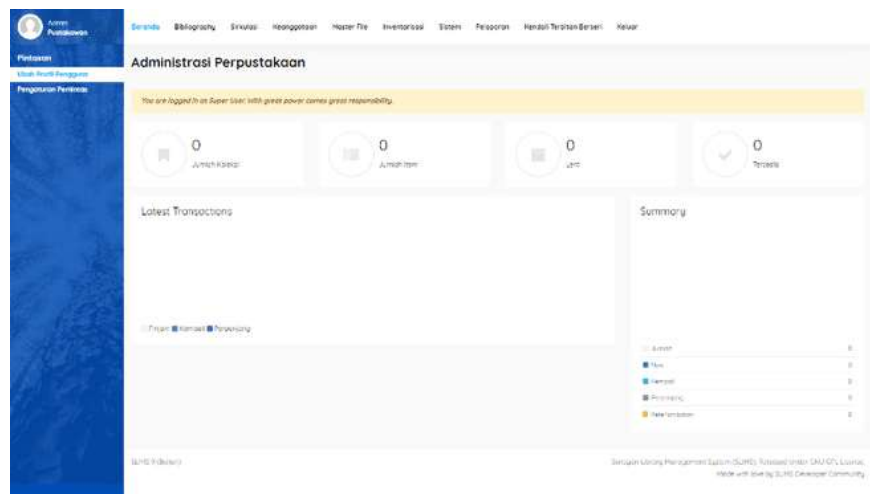

Gambar 3. Tampilan Menu Beranda Admin

b. Menu Bibliografi, pada Menu Bibliografi ini diartikan sebagai pembuatan daftar buku atau artikel majalah untuk subjek tertentu dan fungsinya mendaftar semua buku yang diterbitkan di wilayah geografi negara tertentu dan ditulis dalam Bahasa tertentu. 


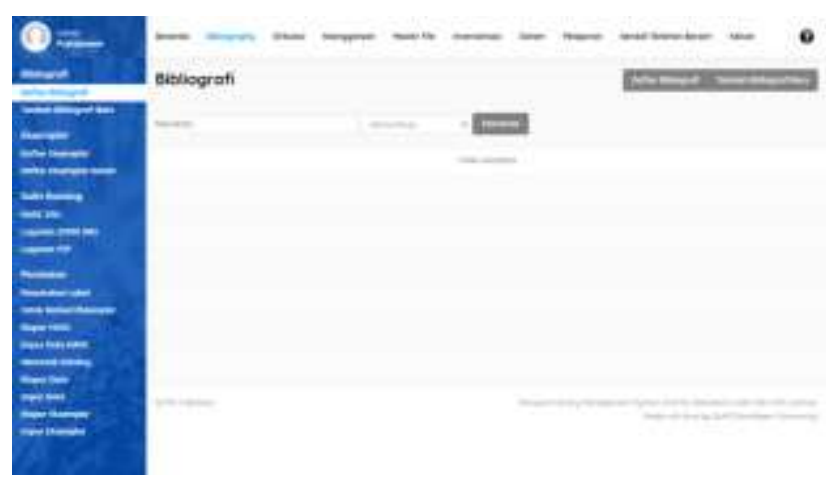

Gambar 4. Tampilan Menu Bibliografi

c. Menu Sirkulasi, Fungsi menu ini adalah untuk layanan pengguna yang terkait dengan peminjaman, pengembalian dan perpanjangan koleksi, serta menu reservasi buku.

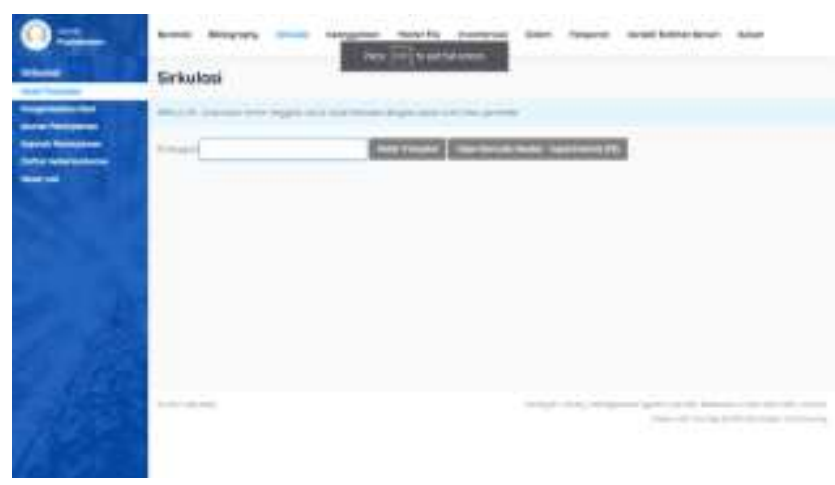

Gambar 5. Tampilan Menu Sirkulasi

d. Menu Keanggotaan, Menu keanggotaan pada SLiMS 9 Bulian dipergunakan untuk mengelola data pemustaka. Data yang dikelola adalah data-data yang diperlukan untuk kegiatan yang berkaitan dengan keperluan perpustakaan khususnya untuk kegiatan sirkulasi. Id, Nama, Tanggal Lahir adalah beberapa diantara data yang akan dikelola melalui menu keanggotaan SLiMS.

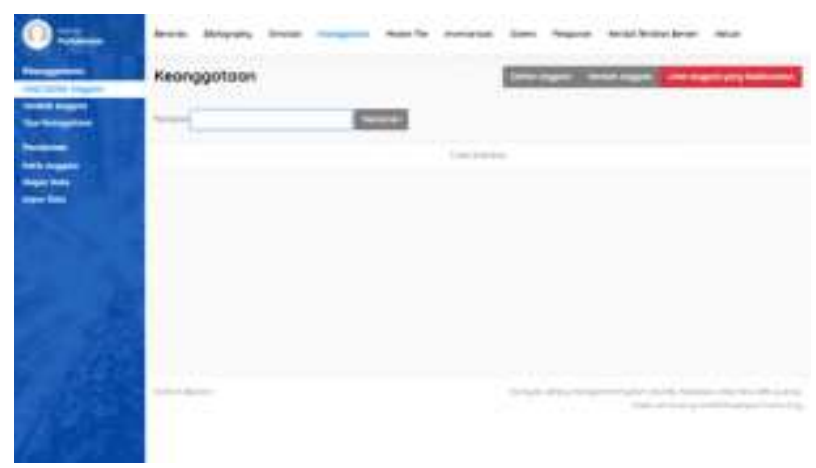

Gambar 6. Tampilan Menu Keanggotaan e. Menu Master File, Menu Master File memungkinkan Pustakawan untuk dapat memasukkan, menghapus dan memperbaiki data yang digunakan sebagai acuan dalam entri data bibliografi.

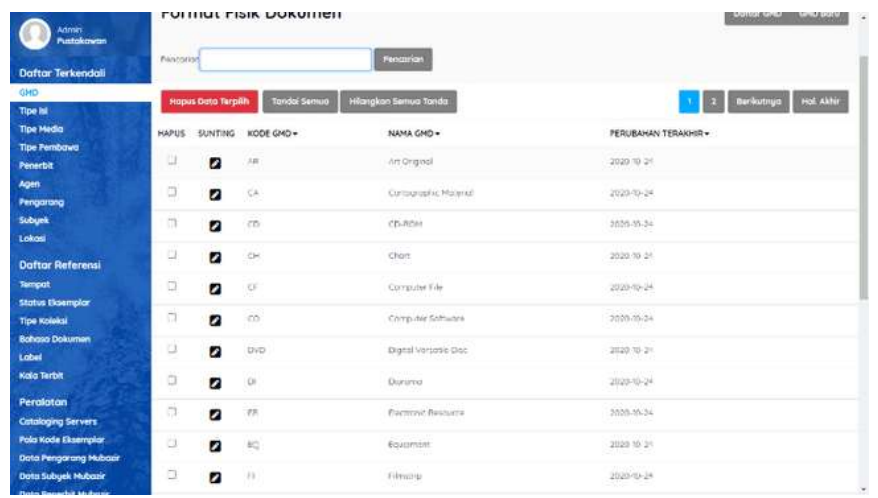

Gambar 7. Tampilan Menu Master File

f. Menu Inventarisasi, fungsi dari menu ini untuk mengecek koleksi secara fisik dan penyesuaian antara koleksi yang sebenarnya yang ada di perpustakaan dengan jumlah koleksi yang ada pada database.

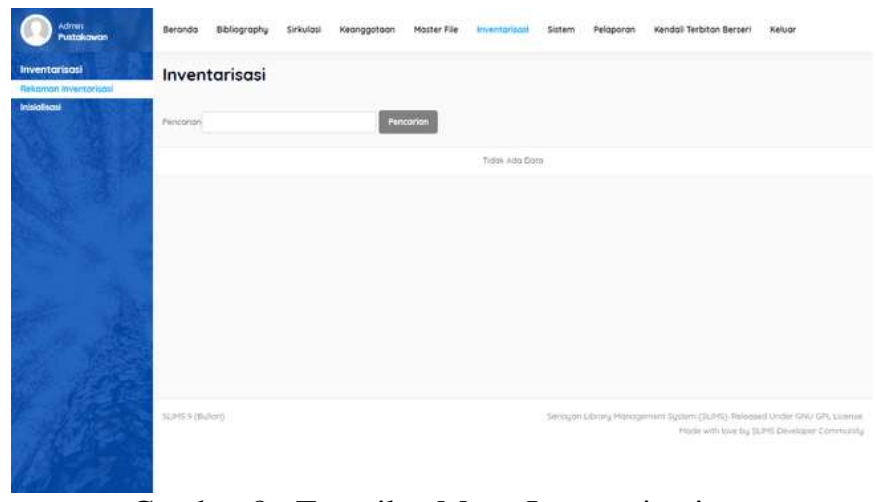

Gambar 8 : Tampilan Menu Inventarisasi

g. Menu System, Pada menu system SLiMS terdapat 14 sub menu. Dimana masing-masing sub menu memiliki fungsi yang berbeda-beda. Diantaranya pengaturan sistem, lingkungan sistem, pengatura UCS, pengaturan tema, konten, indeks bibiliografi, modul, pustakawan dan pengguna sistem, kelompok pengguna, pengaturan pemintas, setelan hari libur, pembuat barkod, catatan sistem, dan Salinan pangkalan data. 


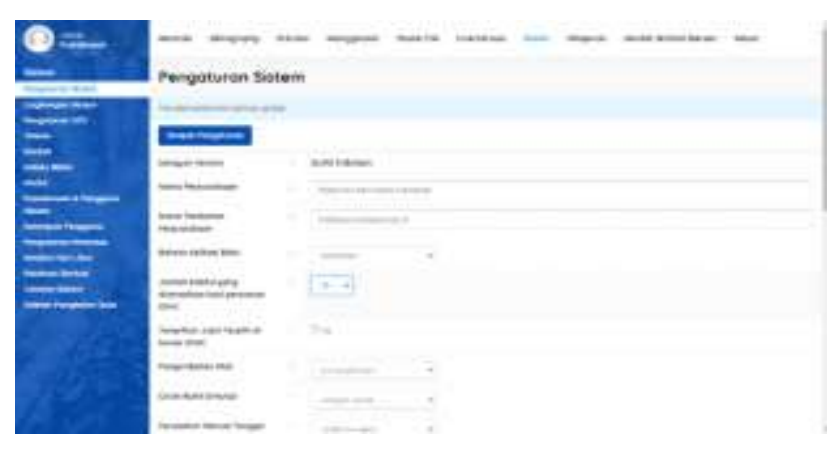

Gambar 9. Tampilan Menu sistem

h. Menu Laporan, berisi tentang laporan-laporan yang masuk ke dalam aktivitas penggunaan SLiMS.

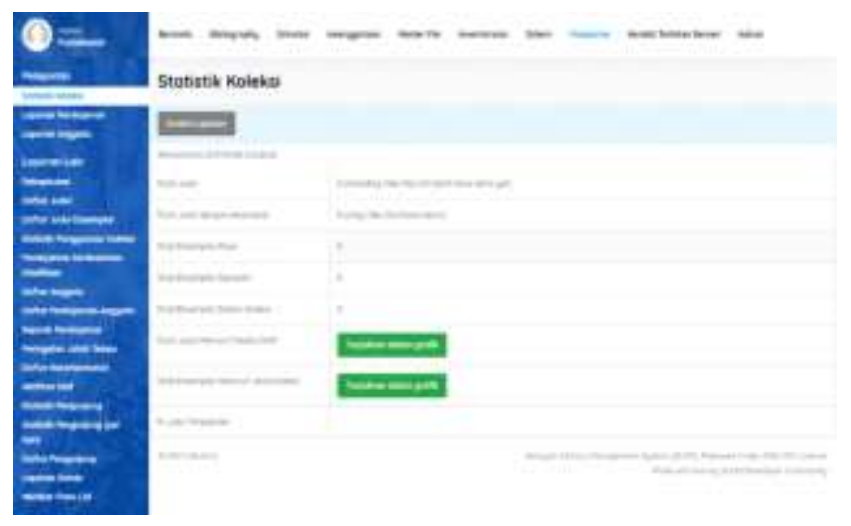

Gambar 10. Tampilan Menu Pelaporan.

i. Menu Kendali Terbitan Berseri, Menu Kendali Terbitan Berseri digunakan untuk memanfaatkan pengecekan koleksi di perpustakaan.

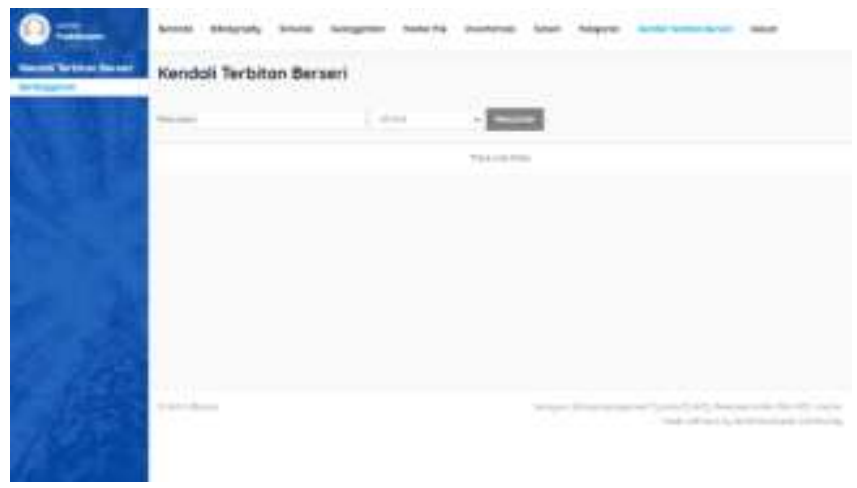

Gambar 11. Tampilan Menu Kendali Terbitan Berseri.

Berdasarkan teori dan penjelasan-penjelasan mengenai aplikasi SliMS, maka aplikasi ini cocok untuk digunakan

Copyright @ 2021 FIKOM - UNASMAN

https://ejournal.fikom-unasman.ac.id di perpustakaan Politeknik Pariwisata Makassar, aplikasi ini bisa digunakan oleh pengelola perpustakaan walaupun tidak mempunyai dasar sebagai pustakawan karena aplikasi ini jelas dan mudah dipahami, mudah dalam penggunaannya. Aplikasi ini sangat membantu pengelola perpustakaan untuk mendapatkan informasi secara cepat dan tepat. Kemudian dengan adanya aplikasi ini, dapat mempercepat pekerjaan karena sudah menggunakan teknologi komputer sehingga diharapkan dapat meningkatkan jumlah pengunjung perpustakaan.

\section{KESIMPULAN}

Penerapan aplikasi SLiMS di perpustakaan Politeknik Pariwisata Makassar adalah pilihan yang tepat bagi pengelola perpustakaan yang bukan merupakan pemustaka. Karena penggunaan aplikasi ini sangat mudah untuk dipahami, sehingga dapat membantu kinerja pengelola perpustakaan. Selain itu, dengan adanya penerapan aplikasi SLiMS ini diharapkan dapat meningkatkan kunjungan ke perpustakaan baik itu secara online maupun offline. Penerapan aplikasi ini juga bisa dikembangkan sesuai dengan kebutuhan pengguna, misalnya dengan menambahkan menu pembuatan surat keterangan bebas Pustaka, baik itu secara offline maupun online, dengan memperhatikan syarat untuk pengambilan surat keterangan tersebut. Menu yang dirasakan tepat untuk pengembangan aplikasi ini juga adalah akses untuk tugas akhir ataupun laporan PKN dalam bentuk soft copy. Sehingga perpustakaan tidak lagi dipenuhi oleh laporan Tugas Akhir ataupun Laporan PKN mahasiswa yang setiap tahun membutuhkan ruang tersendiri Ketika masih dalam bentuk hard copy.

\section{DAFTAR PUSTAKA}

[1] Kemenhumkam. 2009. p. 13 - Kemenhumkam. Undang-undang RI Nomor 43 Tahun 2007. Jakarta: Tamita Utama.

[2] Cohn, J. M., Kelsey, A. L., \& Fiels, K. M. 2001. Planning for Integrated Systems and Technologies: a 11 How-to-do-it Manual for Librarians. Illionis: NealSchuman Publishers

[3] Hendarsyah, D. 2008. Sistem Digitalisasi dan Otomasi Perpustakaan. Ilmu Komputer.Com: ikatlah ilmu dengan manuliskannya. Retrieved October 28, 2013, from http://ilmukomputer.org/2008/09/24/sistemdigitalisasi-dan-otomasi-perpustakaan/. Diakses pada tanggal 15 Oktober 2020

[4] O’Brien, J.A. 2006. Pengantar Sistem Informasi: Perspektif Bisnis dan Manajerial, Edisi Ke-12. Jakarta: Salemba Empat.

[5] Creswell, John W. 2014. Research design pendekatan kualitatif, kuantitatif, dan mixed. Yogyakarta: Pustaka Pelajar 
Jurnal Ilmiah Ilmu Komputer Vol. 7, No. 1, April 2021

Fakultas Ilmu Komputer

(P) ISSN 2442-451X

Universitas AL Asyariah Mandar

(O) ISSN 2503-3832

[6] Sugiyono. (2017). Metode Penelitian Kuantitatif, Kualitatif, dan R\&D. Bandung : Alfabeta, CV.

[7] Mudjia Raharjo. 2017. Studi kasus dalam penelitian kualitatif: konsep dan prosedurnya "skripsi". Malang: UIN Maulana Malik Ibrahim.

[8] Bancin, T. 2015. Persepsi Pemustaka Terhadap OPACSLiMS di Perpustakaan Universitas Bosowa '45' Makassar "skripsi”. Makassar: UIN Alauddin 